\title{
A Study of Seasonal Physicochemical Parameters in River Usma
}

\author{
${ }^{1}$ Ugwu, A.I. and ${ }^{2}$ R.J. Wakawa \\ ${ }^{1}$ Department of Physics, \\ ${ }^{2}$ Department of Chemistry, \\ FCT College of Education Zuba, Abuja, Nigeria
}

Received 2012-05-30, Revised 2012-08-22; Accepted 2012-09-20

\begin{abstract}
Growing populations may put stresses on natural waters by impairing both the quality of the water and the hydrological budget. Abuja, being relatively a new city and the new Federal Capital Territory of Nigeria, has scarce physicochemical data on its water resources that could assist in making robust decision in mitigating the impact of human societies on natural waters; which may not only preserve natural areas, but improve the quality of life of her growing population. A Study of Seasonal Physicochemical Parameters in River Usuma, Abuja Nigeria was carried out between 2011 and 2012. The water quality was studied at seven sites at upstream and downstream among the towns traversed by the River. Physicochemical parameters of the samples were measured; moreover, possible sources of contamination were analyzed. The parameters measured include; sodium $(\mathrm{Na})$, potassium $(\mathrm{K})$, Biochemical Oxygen Demand (BOD); Dissolve Oxygen (DO), pH, temperature, Electrical Conductivity (EC), Total Dissolved Solids (TDS), Total Suspended Solids (TSS), total alkalinity, Total Phosphate (TP), Total Nitrate (TN), Total Sulphate (TS) and Total Chloride (TC). The mean values of the measured parameters were compared with National Standard for Drinking Water Quality (NSDWQ) and U.S. Environmental Protection Agency (USEPA) standards. The findings show that all the physicochemical parameters measured were within the tolerable values except TSS that exceeded with the mean values of $6.8,4.9$ and $8.4 \mathrm{mg} \mathrm{L}^{-1}$ respectively for all the seasons. The values of EC and TDS posed a caution that anthropogenic activities are on the daily increase within the study area. The water resources data base which could have validated the observed values is scarce. Therefore, frequent monitoring of physicochemical parameters of Abuja water resources is imperative.
\end{abstract}

Keywords: Seasonal Variations, River Water, Physicochemical Parameter, Abuja

\section{INTRODUCTION}

The fate and transport of many anthropogenic pollutants are determined by not only hydrological cycles, but also physicochemical processes. Rivers are vital and vulnerable freshwater ecosystems that are critical for the sustenance of all life. However, the declining water quality of these ecological systems threatens their sustainability and is therefore a matter of serious concern. Rivers are waterways of strategic importance across the world, providing main water resources for domestic, industrial and agricultural purposes (Jain, 2009). Untreated discharge of pollutants to a water resource system from domestic sewers, storm water discharges, industrial wastewaters, agricultural runoff and other sources, all can have short term and long term significant effects on the quality of a river system (Singh, 2007). It is a common practice for people living along the river catchments to discharge their domestic waste as well as human excreta into rivers. Wild and Domestic animals using same drinking water can also contaminate the water through direct defecation and urination (Best et al., 1998; Jain, 2009).

Water quality characteristics of aquatic environment arise from a multitude of physical, chemical and biological interactions. A regular monitoring of water bodies with required number of parameters in relation to water quality prevents the outbreak of diseases and Corresponding Author: Ugwu, A.I., Department of Physics, FCT College of Education Zuba, Abuja, Nigeria Tel: +2348036086981 
occurrence of hazards. The quality of River Usuma is relatively unstudied and recently there have been concerns over the water quality of the Usuma River. The issues of major concern are sediments and the impacts of municipal waste water effluents, agricultural land use, deforestation and many other anthropogenic activities on water quality. Municipal waste water effluents and agricultural land use could be raising nutrient levels in this river. Increased nutrients are expected to have an impact on the biological community and water quality of the River Usuma. Bellingham (2012) explained that in order to mitigate the impact human societies have on natural waters, it is becoming increasingly important to implement comprehensive monitoring regimes. He further highlighted that monitoring water resources will quantify water quality, identify impairments and help policy makers make land use decisions that will not only preserve natural areas, but improve the quality of life. Therefore, to assess the present quality of water in River Usuma and the level to which Abuja water resources is polluted, some physicochemical parameters which include Biochemical Oxygen Demand (BOD); Dissolve Oxygen (DO), $\mathrm{pH}$, temperature, Electrical Conductivity (EC), Total Dissolved Solids (TDS), Total Suspended Solids (TSS), total alkalinity, Total Phosphate (TP), Total Nitrate (TN), Total Sulphate (TS) and Total Chloride (TC); were determined. The mean values of these parameters were compared with National Standard for Drinking Water Quality (NSDWQ) and U.S. Environmental Protection Agency (USEPA) standards cited in Zeb et al. (2011).

\section{MATERIALS AND METHODS}

\subsection{Study Area and Monitoring Sites}

The study area is located in the Federal Capital Territory Abuja within the central region of Nigeria. The Usuma River is situated between $9^{\circ} 11^{\prime}$ and $8^{\circ} 55^{\prime}$ North latitude and between $7^{\circ} 24^{\prime}$ and $73^{\circ} 34^{\prime}$ East longitude. The River Usuma is $143 \mathrm{~km}$ in length with its source from Gurara River. It enters FCT through Bwari and exits FCT at Dobi. Very close to first sampling point (Ushafa) Usuman River splits in two directions; with one flowing eastward towards Kpeyi and the other flows westward towards Paiko kore. The climate of the tract is humid temperate with very marked seasonal periods of Harmattan (Winter) between the months of December to early February, dry season between the months of February to late April and rainy season between the months of April to November. Seven monitoring sites were selected near small towns; their locations are as shown in Fig. 1. The latitude and longitudes and the names of the sites are given in Table 1.

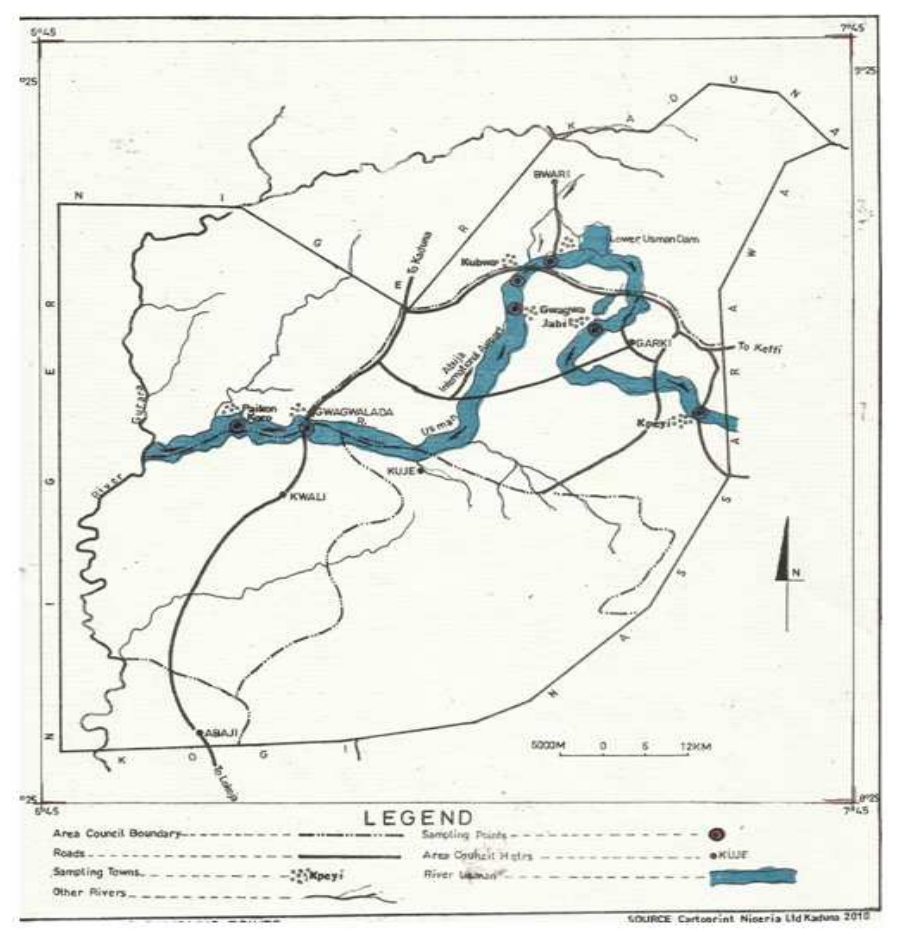

Fig. 1. Area map of federal capital territory abuja showing sampling points' location 
Ugwu, A.I. and R.J. Wakawa / American Journal of Environmental Science 8 (5) (2012) 569-576

Table 1. Names of the sampling locations and their coordinates

\begin{tabular}{llllr}
\hline Sampling sites no. & Name of sampling site & East latitude & North longitude & Elevation from sea level (m) \\
\hline 1 & Ushafa & $7^{\circ} 24^{\prime}$ & $9^{\circ} 11^{\prime}$ & 1500 \\
2 & Kubwa & $7^{\circ} 21^{\prime}$ & $9^{\circ} 09^{\prime}$ & 1300 \\
3 & Gwagwa & $7^{\circ} 20^{\prime}$ & $9^{\circ} 06^{\prime}$ & 1200 \\
4 & G/lada & $7^{\circ} 06^{\prime}$ & $8^{\circ} 56^{\prime}$ & 700 \\
5 & Paiko & $7^{\circ} 00^{\prime}$ & $8^{\circ} 55^{\prime}$ & 500 \\
6 & Jabi & $7^{\circ} 26^{\prime}$ & $9^{\circ} 02^{\prime}$ & 1400 \\
7 & Kpeyi & $7^{\circ} 34^{\prime}$ & $8^{\circ} 57^{\prime}$ & 1300 \\
\hline
\end{tabular}

\subsection{Water Sampling and Chemical Analysis}

Water samples for the dry season were collected during the peak month of the dry season; March 2011. The rainy season samples were equally collected at the peak of the season which was in August 2011. The harmattan samples were collected in the month of January 2012. Figure 1 shows the sampling sites and Table 1 shows the names of location of the sampling sites with coordinates. Grab water samples (1000 mL each) were collected manually at each site using acid-washed $(10 \%, \mathrm{v} / \mathrm{v} \mathrm{HCl})$ into High-Density Polyethylene (HDPE) bottles to avoid any contamination from metal and non-metal ions. The pre-washed bottles were rinsed thrice with water samples on the site before sample collection. Sampling was always done in clear weather condition to prevent any abrupt changes in measurements and to avoid unsteady conditions; sampling was not conducted within 3 to 4 days after rainfall events. Water samples were stored in a cooler box and transported to the laboratory and analysed within a period of 48 hours. The parameters like, $\mathrm{pH}$, EC, DO, temperature were analysed in-situ. Biochemical Oxygen Demand (BOD) concentration was determined by analyzing the oxygen demand using colorimetric method. Also analysed were Total: Sulphate (TS), Phosphate (TP), Nitrate (TN), pH, DO, electrical conductivity, alkalinity (TA) and chloride (TC). $\mathrm{Na}$ and $\mathrm{K}$ were analysed by Jenway flame photometer.

\section{RESULTS AND DISCUSSION}

Seasonal variations in the values of physicochemical parameters at different sampling sites (Ushafa, Kubwa, Gwagwa, Gwagwalada, Paiko, Jabi, Kpeyi), their mean and range along with the NSDWQ and USEPA values for surface waters are shown in Table 5. The study sites' analyses and results for the different seasons are presented in Table 2-4 and their spatial distributions are shown in Fig. 2. Changes in $\mathrm{pH}$ can be indicative of an industrial pollutant, photosynthesis or the respiration of algae that is feeding on a contaminant. Most ecosystems are sensitive to changes in $\mathrm{pH}$ and the monitoring of $\mathrm{pH}$ has been incorporated into the environmental laws of most industrialized countries (Bellingham, 2012). NSDWQ has suggested 6.5-8.5 range of $\mathrm{pH}$ for water for any purposes in that respect; the ranges indicate moderately alkaline water for River Usuma. $\mathrm{pH}$ varied from 6.89-7.53 in dry season, 7.19-7.89 in rainy season and 7.12-7.73 in harmattan (winter) with mean of 7.33, 7.61 and 7.43, respectively. These values are within the range recommended by NSDWQ and USEPA for general purpose water, with respect to $\mathrm{pH}$ (Fig. 2). This alkaline $\mathrm{pH}$ value was also witnessed due to presence of alkaline earth metals ( $\mathrm{Na}$, Table 5) that interact with soluble $\mathrm{CO}_{2}$ forming carbonates and bicarbonate which results in shifting the $\mathrm{pH}$ up over 7 . The alkalinity of natural waters is controlled by the concentration of hydroxide and represented by a $\mathrm{pH}$ greater than 7 . Other contributors to an alkaline $\mathrm{pH}$ include boron, phosphorous, nitrogen containing compounds and potassium. Total Dissolved Solids (TDS) further indicate the salinity behavior of river water. TDS content of the river water was in the range of $48.80-179.50 \mathrm{mg} \mathrm{L}^{-1}$; $168.90-465.20 \mathrm{mg} \mathrm{L}^{-1}$ and $133.20-320.10 \mathrm{mg} \mathrm{L}^{-1}$ with mean of $105.19,262.95$ and $226.70 \mathrm{mg} \mathrm{L}^{-1}$ in dry, rainy and harmattan seasons respectively. Appreciable TDS values were observed at all the sampling sites indicating the mixing of pollutants in river from anthropogenic activities in and around the river, such as the mixing of sewerage, clothes washing and garbage dumping, which are some common activities at the riverbank in this area. Gwagwa shows a value that doubles the values of the rest relatively in all the seasons, which indicates that anthropogenic activities within this area are of concerned interest with respect to pollution. Increasing order of TDS was observed from upstream (Ushafa) to westward downstream (Paiko), reaching maximum at Gwagwa after which a decrease is observed in the downstream sites (Fig. 2). The observed value at Paiko significantly departed from theory, considering the distance between its adjacent sampling points. It is expected that the value would reduce due to turbulence and natural self-cleaning of flowing water. Thus the result suggests possible anthropogenic activities within the riverbank of the site. Higher TDS in water system increases the chemical and biological oxygen demand and ultimately depletes the dissolved oxygen level in water. 
Ugwu, A.I. and R.J. Wakawa / American Journal of Environmental Science 8 (5) (2012) 569-576

Table 2. Total metal concentrations and physicochemical parameters in water; dry season March 2011

\begin{tabular}{|c|c|c|c|c|c|c|c|}
\hline \multirow[b]{2}{*}{$\begin{array}{l}\text { Physiochemical } \\
\text { parameter }\end{array}$} & \multicolumn{7}{|c|}{ Sampling sites } \\
\hline & $\begin{array}{l}1 \\
\text { Ushafa }\end{array}$ & $\begin{array}{l}2 \\
\text { Kubwa }\end{array}$ & $\begin{array}{l}3 \\
\text { Gwagwa }\end{array}$ & $\begin{array}{l}4 \\
\text { G/Lada }\end{array}$ & $\begin{array}{l}5 \\
\text { Paiko }\end{array}$ & $\begin{array}{l}6 \\
\text { Jabi }\end{array}$ & $\begin{array}{l}7 \\
\text { Kpeyi }\end{array}$ \\
\hline $\mathrm{Na}$ & 1.15 & 1.60 & 1.05 & 2.10 & 1.20 & 2.71 & 1.55 \\
\hline $\mathrm{K}$ & 0.80 & 0.45 & 0.35 & 1.00 & 1.40 & 2.45 & 0.62 \\
\hline $\mathrm{pH}$ & 7.50 & 6.89 & 7.50 & 7.53 & 7.22 & 7.44 & 7.23 \\
\hline TDS(mg/L) & 48.80 & 94.40 & 114.70 & 102.40 & 179.50 & 92.00 & 104.50 \\
\hline Cond $\mu \mathrm{s}$ & 81.30 & 158.00 & 191.30 & 170.00 & 299.00 & 153.80 & 174.20 \\
\hline Alkalinity & 2.19 & 1.56 & 2.46 & 2.72 & 2.10 & 1.84 & 3.16 \\
\hline$\% \mathrm{DO}_{2}$ & 80.00 & 104.00 & 23.00 & 86.00 & 75.00 & 130.00 & 131.00 \\
\hline $\mathrm{BOD}$ & 8.49 & 16.70 & 2.39 & 11.84 & 7.80 & 7.64 & 14.30 \\
\hline TSS (mg/L) & 2.19 & 6.44 & 7.66 & 2.81 & 3.11 & 3.61 & 6.21 \\
\hline Turb & 4.06 & 195.00 & 246.00 & 119.00 & 34.10 & 3.24 & 43.40 \\
\hline Sulphate $(\mathrm{mg} / \mathrm{L})$ & 17.20 & 191.60 & 2012.00 & 1440.80 & 91.50 & 25.90 & 204.50 \\
\hline Phosphate(mg/L) & 0.44 & 1 & 1.66 & 3.88 & 0.44 & 0.33 & 1.22 \\
\hline Nitrate $(\mathrm{mg} / \mathrm{L})$ & 0.01 & $\mathrm{BD}$ & 0.07 & BD & 0.10 & 0.25 & BD. 00 \\
\hline Chloride $(\mathrm{mg} / \mathrm{L})$ & ${ }^{\mathrm{a}} \mathrm{BD}$ & $\mathrm{BD}$ & 0.19 & $\mathrm{BD}$ & BD & 0.05 & 0.09 \\
\hline
\end{tabular}

${ }^{\mathrm{a}} \mathrm{BD}$ : Bellow Detection limit

Table 3. Total metal concentrations and physicochemical parameters in water; rainy season July 2011

\begin{tabular}{|c|c|c|c|c|c|c|c|}
\hline \multirow[b]{2}{*}{$\operatorname{Metal}(\mathrm{mg} / \mathrm{L}) \pm \operatorname{Rsd}(\%)$} & \multicolumn{7}{|c|}{ Sampling sites } \\
\hline & $\begin{array}{l}1 \\
\text { Ushafa }\end{array}$ & $\begin{array}{l}2 \\
\text { Kubwa }\end{array}$ & $\begin{array}{l}3 \\
\text { Gwagwa }\end{array}$ & $\begin{array}{l}4 \\
\text { G/Lada }\end{array}$ & $\begin{array}{l}5 \\
\text { Paiko }\end{array}$ & $\begin{array}{l}6 \\
\text { Jabi }\end{array}$ & $\begin{array}{l}7 \\
\text { Kpeyi }\end{array}$ \\
\hline $\mathrm{Na}$ & 2.29 & 2.46 & 1.50 & 2.56 & 2.79 & 3.12 & 1.55 \\
\hline $\mathrm{K}$ & 1.24 & 1.26 & 0.82 & 1.29 & 2.13 & 3.15 & 0.62 \\
\hline $\mathrm{pH}$ & 7.69 & 7.44 & 7.89 & 7.19 & 7.55 & 7.66 & 7.88 \\
\hline $\mathrm{TDS}(\mathrm{mg} / \mathrm{L})$ & 168.90 & 292.50 & 465.20 & 284.60 & 284.00 & 286.40 & 340.20 \\
\hline Cond $\mu \mathrm{s}$ & 316.00 & 360.00 & 349.00 & 540.00 & 450.00 & 223.10 & 442.30 \\
\hline Alkalinity & 3.49 & 2.91 & 2.15 & 5.44 & 3.89 & 2.46 & 3.55 \\
\hline$\% \mathrm{DO}_{2}$ & 94.50 & 98.40 & 79.00 & 99.50 & 89.00 & 97.00 & 110.00 \\
\hline $\mathrm{BOD}$ & 7.49 & 20.64 & 4.12 & 19.42 & 10.54 & 7.49 & 18.40 \\
\hline $\mathrm{TSS}(\mathrm{mg} / \mathrm{L})$ & 4.41 & 12.33 & 5.99 & 8.42 & 4.72 & 4.51 & 5.92 \\
\hline Turb & 56.20 & 290.00 & 213.00 & 180.00 & 55.20 & 5.64 & 25.60 \\
\hline Sulphate(mg/L) & 10.56 & 246.00 & 1920.00 & 920.00 & 105.00 & 23.40 & 150.40 \\
\hline $\operatorname{Phosph}(\mathrm{mg} / \mathrm{L})$ & 5.84 & 4.96 & 6.62 & 10.56 & 4.60 & 2.76 & 5.69 \\
\hline Nitrate $(\mathrm{mg} / \mathrm{L})$ & 0.44 & 1.60 & 2.50 & 0.15 & 2.54 & 1.50 & 2.40 \\
\hline Chloride(mg/L) & 0.14 & 0.560 & 1.80 & 1.75 & 2.19 & 0.15 & 1.80 \\
\hline
\end{tabular}

Table 4. Total metal concentrations and physiochemical parameters in water; harmattan Feb. 2012

\begin{tabular}{|c|c|c|c|c|c|c|c|}
\hline \multirow[b]{2}{*}{$\operatorname{Metal}(\mathrm{mg} / \mathrm{l}) \pm \operatorname{Rsd}(\%)$} & \multicolumn{7}{|c|}{ Sampling sites } \\
\hline & $\begin{array}{l}1 \\
\text { Ushafa }\end{array}$ & $\begin{array}{l}2 \\
\text { Kubwa }\end{array}$ & $\begin{array}{l}3 \\
\text { Gwagwa }\end{array}$ & $\begin{array}{l}4 \\
\text { G/Lada }\end{array}$ & $\begin{array}{l}5 \\
\text { Paiko }\end{array}$ & $\begin{array}{l}6 \\
\text { Jabi }\end{array}$ & $\begin{array}{l}7 \\
\text { Kpeyi }\end{array}$ \\
\hline$\overline{\mathrm{Na}}$ & 1.92 & 1.78 & 1.84 & 1.88 & 1.99 & 2.15 & 1.61 \\
\hline $\mathrm{K}$ & 0.89 & 0.89 & 0.88 & 0.94 & 0.95 & 0.97 & 0.91 \\
\hline $\mathrm{pH}$ & 7.73 & 7.12 & 7.46 & 7.23 & 7.49 & 7.55 & 7.14 \\
\hline $\mathrm{TDS}(\mathrm{mg} / \mathrm{L})$ & 133.20 & 256.30 & 284.00 & 274.30 & 243.10 & 208.40 & 320.10 \\
\hline Cond $\mu \mathrm{s}$ & 284.00 & 18.00 & 223.10 & 497.00 & 340.00 & 227.60 & 356.10 \\
\hline Alkalinity & 1.77 & 1.28 & 0.57 & 4.38 & 2.10 & 0.56 & 1.89 \\
\hline$\% \mathrm{DO}_{2}$ & 95.00 & 96.20 & 88.00 & 95.00 & 93.00 & 92.00 & 91.00 \\
\hline $\mathrm{BOD}$ & 8.49 & 22.56 & 7.19 & 19.23 & 15.46 & 9.46 & 15.80 \\
\hline $\mathrm{TSS}(\mathrm{mg} / \mathrm{L})$ & 5.11 & 8.94 & 5.77 & 7.62 & 5.88 & 5.62 & 4.62 \\
\hline Turb & 2.89 & 18.90 & 246.00 & 76.30 & 4.62 & 1.56 & 3.45 \\
\hline Sulphate(mg/L) & 8.14 & 222.00 & 680.00 & 182.00 & 88.90 & 9.46 & 144.00 \\
\hline Phosphate(mg/L) & 4.55 & 3.62 & 8.22 & 4.41 & 3.66 & 0.88 & 2.80 \\
\hline Nitrate (mg/L) & ${ }^{\mathrm{a}} \mathrm{BD}$ & $\mathrm{BD}$ & $\mathrm{BD}$ & 0.09 & 0.12 & $\mathrm{BD}$ & 0.15 \\
\hline Chloride $(\mathrm{mg} / \mathrm{L})$ & BD & BD & 0.24 & BD & 0.11 & 0.1 & 0.08 \\
\hline
\end{tabular}

${ }^{\mathrm{a}} \mathrm{BD}$ : Bellow Detection limit 
Ugwu, A.I. and R.J. Wakawa / American Journal of Environmental Science 8 (5) (2012) 569-576

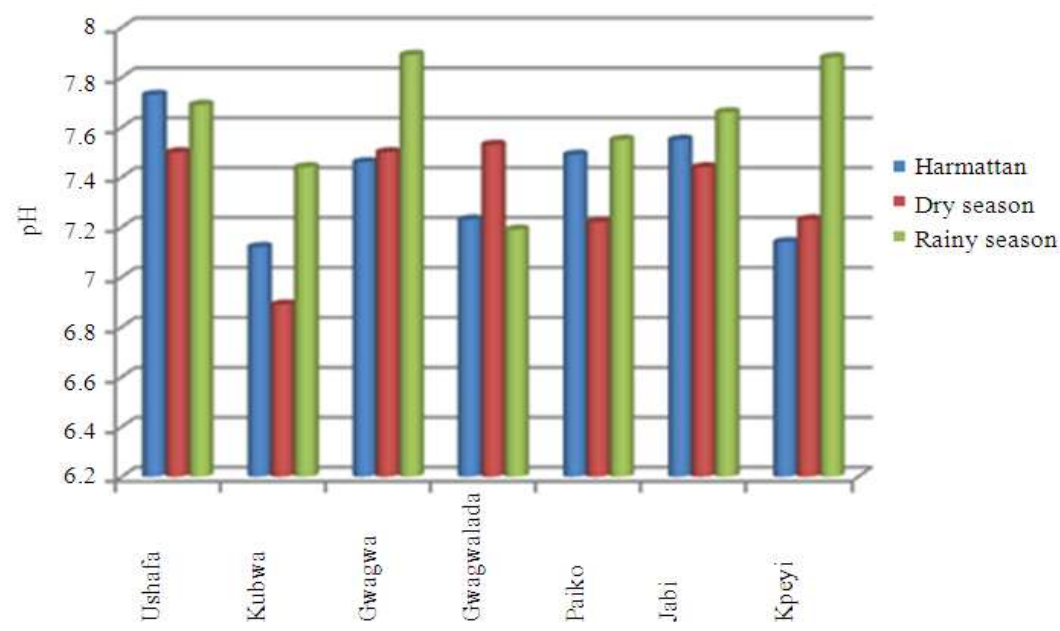

(a)

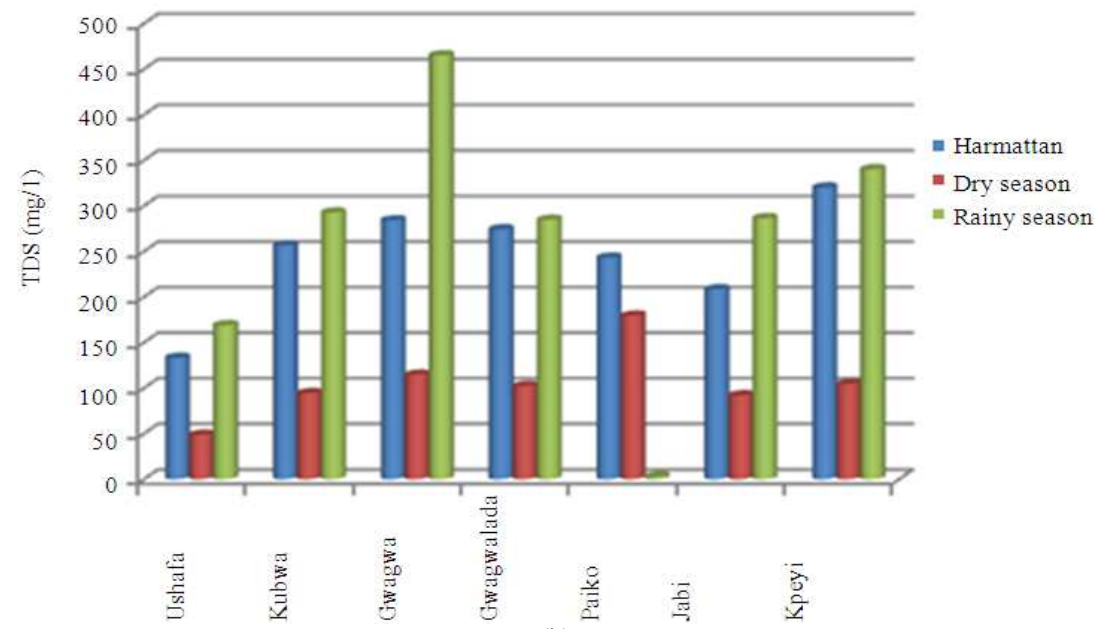

(b)

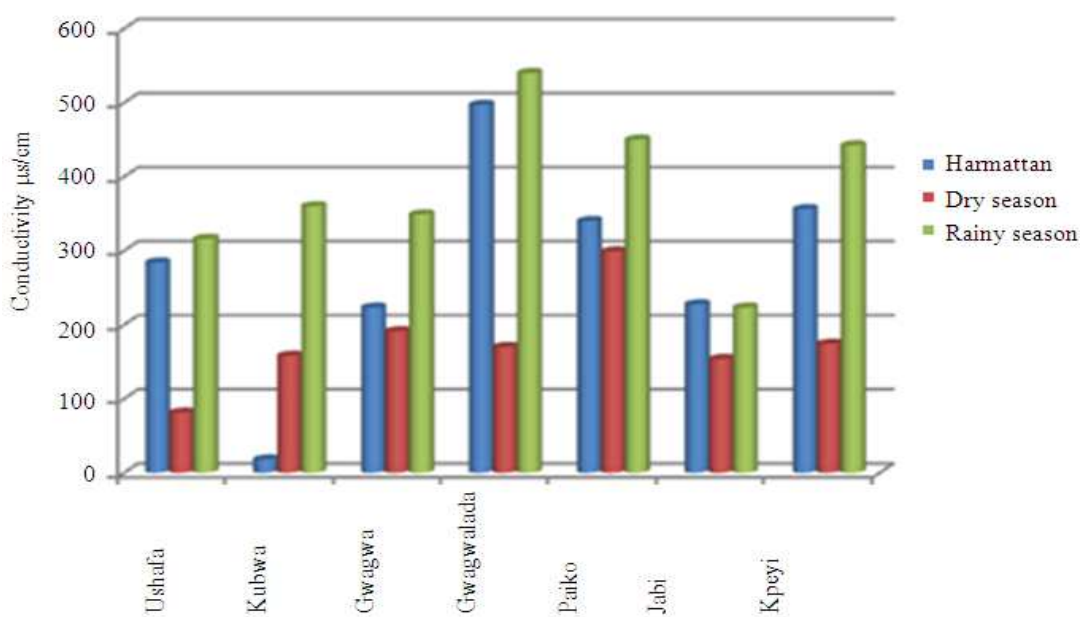

(c) 
Ugwu, A.I. and R.J. Wakawa / American Journal of Environmental Science 8 (5) (2012) 569-576
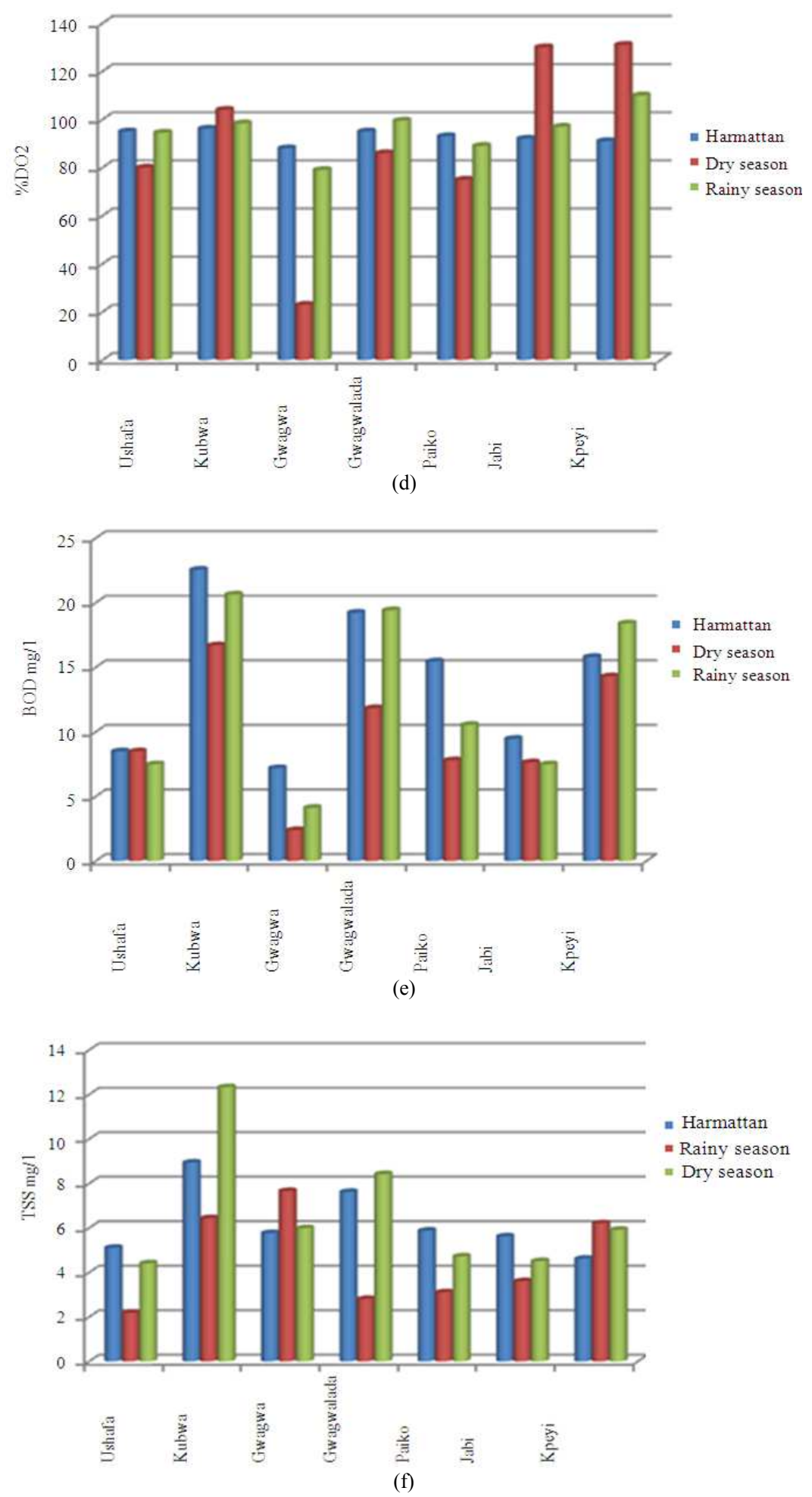

Fig. 2. Variations of physiochemical parameters in dry, rainy and harmattan seasons for various sampling sites 
Ugwu, A.I. and R.J. Wakawa / American Journal of Environmental Science 8 (5) (2012) 569-576

Table 5. Means and ranges of water quality parameters of the river usuma along with standard limits of NSDWQ and USEPA $\mathrm{f}$ Usuma River

\begin{tabular}{|c|c|c|c|c|c|}
\hline Parameter & NSDW QPak & USEPA & Harmattan mean(range) & Dry season mean/(range) & Rainy season mean(range) \\
\hline Temperature & & & 29 & 33 & 31 \\
\hline $\mathrm{pH}$ & $6.5-8.5$ & $6.5-8.5$ & $7.43(7.12-7.73)$ & $7.2(6.9-7.5)$ & $7.5(7.2-7.9)$ \\
\hline TDS (mg/L & $<1000$ & 500 & $226.7(133-320)$ & $114.2(49-180)$ & $316(169-462)$ \\
\hline $\mathrm{EC}(\mu \mathrm{s} / \mathrm{mm})$ & - & $10-1000$ & $257.5(18-497)$ & $190.2(81.3-299)$ & $381(223-540)$ \\
\hline Alkalinity & $<500$ & - & $2.5(0.56-4.38)$ & $2.4(1.56-3.16)$ & $3.8(2.2-5.4)$ \\
\hline $\mathrm{DO}(\mathrm{mg} / \mathrm{L})$ & - & $40.0-60.0$ & $92.0(88.0-96.0)$ & $77.0(23.0-131.0)$ & $94.5(79-110)$ \\
\hline $\mathrm{COD}(\mathrm{mg} / \mathrm{L})$ & - & 4 & $13.2(7.2-19.2)$ & $9.6(2.4-16.7)$ & $12.4(4.1-20.6)$ \\
\hline $\mathrm{TSS}(\mathrm{mg} / \mathrm{L})$ & - & 5 & $6.8(4.6-8.9)$ & $4.9(2.2-7.7)$ & $8.4(4.4-12.3)$ \\
\hline Turb ${ }^{a}$ (NTU) & & $1-2000$ & $123.8(1,6-246)$ & $125(4-246)$ & $147.8(5.6-290.0)$ \\
\hline Sulphate $(\mathrm{mg} / \mathrm{L})$ & - & 250 & $344.1(8.1-680)$ & $110.9(17.2-205)$ & $101.3(10.6-192)$ \\
\hline Phosph. $(\mu \mathrm{g} / \mathrm{L})$ & - & $<100$ & $4.6(0.9-8.2)$ & $2.1(0.3-3.9)$ & $6.7(2.8-10.6)$ \\
\hline Nitrate $(\mathrm{mg} / \mathrm{L})$ & $<53$ & 10 & $7.6(0.1-15.0)$ & $0.1(0.0-0.25)$ & $1.5(0.4-2.5)$ \\
\hline Chloride $(\mathrm{mg} / \mathrm{L})$ & $<250$ & 250 & $0.1(.08-0.11)$ & $0.1(0-0.2)$ & $1.2(0.1-2.2)$ \\
\hline
\end{tabular}

${ }^{\mathrm{a}}$ Nephelometric Turbidity Unit (NTU)

Electrical Conductivity (EC) in natural waters is the normalized measure of the water's ability to conduct electric current. This is mostly influenced by dissolved salts such as sodium chloride and potassium chloride. Most freshwater sources will range between 0.1-10 $\mu \mathrm{s} / \mathrm{cm}$. Field measurements of EC reflect the amount of Total Dissolved Solids (TDS) in natural waters. EC of River Usuma water was significantly different among sampling sites and in all the seasons, however higher in rainy season than dry and harmattan seasons. Higher values of rainy season are possibly due to storm water runoff that brings in lots of water from the farms with dissolved conducting minerals. These values vary from 81.30 to $299.00 ; 223.10-540.00$ and $18.00-497.00 \mu \mathrm{s}$ $\mathrm{mm}^{-1}$; with mean values of $190.15,381.55$ and 257.50 $\mu \mathrm{s} \mathrm{mm}^{-1}$ in dry, rainy and harmattan seasons, respectively (Fig. 2 and Table 2). High conductivity at the sites indicates the mixing of sewerage in river water as these sites are located near populated towns. The high conductivity possibly due to sewerage at the sites also suggests that the River Usuman serves as primary source of domestic water to most of these towns (Hassan et al., 2009).

Dissolved Oxygen (DO) is essential to all forms of aquatic life including the organisms that break down man-made pollutants. Oxygen is soluble in water and the oxygen that is dissolved in water will equilibrate with the oxygen in atmosphere. Oxygen tends to be less soluble as temperature increases. The DO of fresh water at sea level will range from $150 \%$ at $0^{\circ} \mathrm{C}-80 \%$ at $25^{\circ} \mathrm{C}$. Concentrations of unpolluted fresh water will be close to $100 \%$ (Kannel et al., 2007). DO of River Usuma ranged between $23-131,79-110$ and $88-96 \%$ with mean values of $77.0,94.5$ and $92.0 \%$ in dry, rainy and harmattan seasons, respectively. There is no defined trend in variation of maximum mean value of $\% \mathrm{DO}$ among the sites in all the seasons (Fig. 2). This indicated that the turbulences and flow rate of river water at different sites, which may be beneficial for dissolved solid breakdown through self-pollution regulating mechanisms of fresh water system was not found here (Hassan et al., 2009). It then means that each sampling site was instantaneously been polluted by anthropogenic activities around it ( $\mathrm{Li}$ et al., 2011). The quality of the water in terms of DO content is always of primary importance, because at the waste discharge points in river, the DO is required for aerobic oxidation of the wastes. Also, Zeb et al. (2011) explained that DO levels are important in the natural self-purification capacity of the river. A good level of DO in sampling sites of the river indicated a high re-aeration rate and rapid aerobic oxidation of biological substances. The values DO obtained at different sites are well above the values recommended by USEPA (Table 5), which indicate low level of anthropogenic activities within the study area.

Other indirect laboratory tests for assessing the DO is the Biological Oxygen Demand (BOD) which is the amount of oxygen required to biologically break down a contaminant. It is often used as a measurement of pollutants in natural and waste waters and to assess the strength of waste, such as sewage and industrial effluent waters (Zeb et al., 2011). BOD therefore is an important parameter of water indicating the health scenario of freshwater bodies (Bhatti and Latif, 2011). In the present study, BOD varied from 2.-16.70, 4.12-20.64 and 7.19-19.23 $\mathrm{mg} \mathrm{L}^{-1}$ with mean value of $9.55,12.38$ and $13.21 \mathrm{mg} \mathrm{L}^{-1}$ in dry, rainy and harmattan seasons respectively (Fig. 2 and Table 5). No trend was found downstream of the sampling sites, which further confirmed non- existence of point source pollution, but rather; instantaneous pollution of the sampled sites. 
Turbidity and Total Suspend Solids (TSS) are the materials in water that affect the transparency or light scattering of the water. The observed values of turbidity were within the limit range (Table 5). TSS is typically composed of fine clay or silt particles, plankton, organic compounds, inorganic compounds or other microorganisms. These suspended particles range in size from $10-0.1 \mathrm{~mm}$ although in standardized laboratory tests, TSS is defined as the material that cannot pass through a $45 \mu \mathrm{m}$ diameter filter. TSS as well as TDS can be influenced by changes in $\mathrm{pH}$. Changes in the $\mathrm{pH}$ will cause some of the solutes to precipitate or will affect the solubility of the suspended mater (Bellingham, 2012). The Total Suspended Solid (TSS) exceeded the limit values in all the seasons (Table 5). This could be attributed to stormwater runoff, anthropogenic activities, such as sharp sand fetching constantly going on in the river and atmospheric particle deposits

Nitrate levels over $10 \mathrm{mg} \mathrm{L}^{-1}$ in natural waters normally indicate man made pollution, but the measured values in this study were within the limit range; as shown in Table 5. Man made sources of include, fertilizers, livestock, urban runoff, septic tanks and waste water discharges. As more land is converted into agricultural land and as urban areas expand, nitrate monitoring is an important tool in accessing locating and mitigating man made sources of nitrate. Man made sources of phosphate in the environment include domestic and industrial discharges, agricultural runoff where fertilizers are used and changes in land use in areas where phosphorous is naturally abundant in the soil. In general, phosphates are not very toxic to people or other living organisms. The values measured in this study were insignificant (Table 5).

Chloride content in River Usuma varied from 0.05$0.19,0.14-2.18$ and $0.080 .11 \mathrm{mg} \mathrm{L}^{-1}$ with mean values of $0.12,1.17$ and $0.095 \mathrm{mg} \mathrm{L}^{-1}$ in dry, rainy and harmattan seasons, respectively (Table 5). The values of chloride observed in this study are not significant when compared to tolerable values posted by USEPA though chloride contents in water are not harmful. Also, chloride concentration at different sampling sites did not exhibit a clear trend with respect to point or non-point pollution sites. Nitrate, phosphate and sulfate are important parameters of river water showing the pollution status and anthropogenic load in river water (Khan and Khan, 1997). There range and mean values are shown in Table $\mathbf{5}$ and they are within acceptable limit in all the seasons.

\section{CONCLUSION}

The water quality of the River Usuma is relatively safe with respect to physiochemical parameters recorded in this study. This is a pointer that the environment of Abuja for now has a low industrial load. There were significant occurrence in EC, TDS and TSS which call for caution on discharge untreated waste into River Usuma. The sampling sites near populated towns of Kubwa, Gwagwa and Gwagwalada were found to be most contaminated; this load is more prominent in rainy season as compared to dry and harmattan seasons and hence cannot be used for drinking purpose; however, other water activities can be performed easily in consideration of physicochemical parameters.

\section{ACKNOWLEDGEMENT}

The present study was supported by Tertiary Education Trust Fund (TETFund) and Advanced Chemistry Laboratory of Sheda Science and Technology Complex (SHESTCO) Abuja.

\section{REFERENCES}

Bellingham, K., 2012. Stevens water monitoring systems.

Best, G.A., T. Bogacka and E. Niemirycz, 1998. International River Water Quality: Pollution and Restoration. 1st Edn., Taylor and Francis, London UK., ISBN-10: 0419215409, pp: 310.

Bhatti, M.T. and M. Latif, 2011. Assessment of water quality of a river using an indexing approach during the low-flow season. Irrigation Drainage, 60: 103114. DOI: $10.1002 /$ ird.549

Hassan, F.M., M.M. Saleh and J.M. Salman, 2009. A Study of Physicochemical Parameters and Nine Heavy Metals in the Euphrates River, Iraq. E-J. Chem., 7: 685-692. DOI: 10.1155/2010/906837

Jain, A.K., 2009. River Pollution. 1st Edn., APH Publishing, New Delhi, ISBN: 8131304639, pp: 330.

Kannel, P.R., S. Lee, Y.S. Lee, S.R. Kanel and S.P. Khan, 2007. Application of water quality indices and dissolved oxygen as indicators for river water classification and urban impact assessment. Environ. Monit Assess., 132: 93-110. PMID: 17279460

Khan, S.A. and M. Khan, 1997. Water quality characteristics of the Kabul river in Pakistan under high flow conditions. J. Chem. Soc. Pak., 19: 205-210.

Li, J., H. Li, B. Shen and Y. Li, 2011. Effect of nonpoint source pollution on water quality of the Weihe River. Int. J. Sed. Res., 26: 50-61. DOI: 10.1016/S1001-6279(11)60075-9

Singh, L.B., 2007. River Pollution. 1st Edn., APH Publishing, New Delhi, ISBN-10: 8131300854, pp: 192.

Zeb, B.S., A.H. Malik, A. Waseem and Q. Mahmood, 2011. Water quality assessment of Siran river, Pakistan. Int. J. Phys. Sci., 6: 7789-7798. 